Отримано: 31 серпня 2021 року

Прорецензовано: 6 вересня 2021 року

Прийнято до друку: 20 вересня 2021 року

e-mail: lyashchenko1981@ukr.net

pylypchuk0608@gmail.com

vereschagina_tet@ukr.net

DOI: 10.25264/2519-2558-2021-11(79)-206-209
Liashchenko O. A., Pylypchuk T. V., Vereshchahina T. O. Biology students' perceptions of internet resources in learning English for academic purposess. Наукові записки Національного університету «Острозька академія»: серія «Філологія». Острог : Вид-во НаУОА, 2021. Вип. 11(79). С. 206-209.

\author{
Olesia Liashchenko, \\ PhD in Philology, Associate Professor, \\ National Taras Shevchenko University of Kyiv \\ Tetiana Pylypchuk, \\ Assistant, \\ National Taras Shevchenko University of Kyiv \\ Tetiana Vereshchahina, \\ PhD in Pedagogy, Senior teacher, \\ National University 'Kyiv Mohyla Academy'
}

\title{
BIOLOGY STUDENTS' PERCEPTIONS OF INTERNET RESOURCES IN LEARNING ENGLISH FOR ACADEMIC PURPOSES
}

The outbreak of Coronavirus disease (COVID-19) has accelerated the process of digitalization in higher education setting and the field of learning English for academic purposes is no exception. An adequate selection of available online resources of high didactic and pedagogical value that could facilitate EAP learning is an urgent issue. The aim of the article is to investigate biology students' evaluation of 6 internet resources (FutureLearn, Khan Academy, tutorial channels on Youtube (namely, CrashCourse and RicochetScience), Quizlet, Kahoot, Crossword Labs) that were used during the academic year 2020-2021 as supplementary tools for achieving learning objectives in the framework of disciplinary course 'English for Biologists (freshmen).' In order to achieve the purpose of the research quantitative and qualitative surveys were conducted among first-year biology students. Collected data revealed their preferences regarding 3 sections in the evaluation of internet resources: design (user-friendly browsing, absence of technical errors), information reliability and accuracy, promotion of learners' interaction and engagement. Also, the data showed students' self-assessment of linguistic skills they improved by utilizing these resources. The study of students' perceptions of internet resources helps to define useful internet tools to make distant learning of Academic English for Biology more meaningful and effective.

Key words: digitalization of higher education, Covid-19 pandemic, Academic English for Biology.

\author{
Лященко Олеся Анатолї̈вна, \\ кандидат філологічних наук, доцент, \\ Київський начіональний університет ім. Тараса Шевченка \\ Пилипчук Тетяна Володимирівна, \\ асистент, \\ Київський національний університет ім. Тараса Шевченка \\ Верещагіна Тетяна Олександрівна, \\ доктор філософії з педагогіки, стариий викладач, \\ Наиіональний університет «Києво-Могилянська Академія»
}

\section{ІНТЕРНЕТ РЕСУРСИ ДЛЯ ВИВЧЕННЯ АНГЛІЙСЬКОЇ МОВИ ЗА АКАДЕМІЧНИМ СПРЯМУВАННЯМ: РЕЦЕПЦІЯ СТУДЕНТІВ БІОЛОГІЧНОЇ ГАЛУЗІ}

В умовах пандемї, спричиненої поширенням вірусу СОVID-19, виникла гостра потреба перелаштувати навчальний процес у ВНЗ з традииійного очного або зміманого формату в дистаниійний. Викладачі англійської мови для немовних спечіальностей зіткнулися з проблемою пошуку доступних навчальних інтернет ресурсів, які б могли сприяти вивченню англійської онлайн. У статті проаналізовано відозви студентів-біологів периого курсу про 6 навчальний сайтів, які використовувалися як додаткові навчальні ресурси для вивчення академічної англійської для біологів упродовж 2021-2022 н. р. У результаті дослідження було з 'ясовано, які мовні навички, на думку студентів, покрашчлись у результаті використання інтернет ресурсів та які з цих віртуальних продуктів студенти вважають найкращими за трьома параметрами: технічними (зрозумілість інтерфейсу, зручність навігаџї по сайту), змістовими (інформаційна надійність і точність навчального контенту) та дидактичними (різноманіття вправ для практичного засвоєння матеріалу).

Ключові слова: цчифровізація вищзої освіти, пандемія Соvіd-19, академічна англійська біологічного спрямування.

Introduction. In the last decade, information and communication technologies have been rapidly penetrating into all spheres of social life including higher education. This trend has proven to be a necessary step in implementing distance academic learning as well as increasing the competitiveness of universities and improving job opportunities for graduates in a labour market. The outbreak of Coronavirus disease (COVID-19) has accelerated the process of digitalization in higher education setting so that now there is an urgent need to build up a sustainable and effective model of knowledge acquisition through utility of online tools and the field of learning English for academic purposes (EAP) is no exception. The search for effective ready-to-use online resources that could be used to facilitate the learning of EAP is one of the numerous challenges English instructors are facing now due to the COVID-19 pandemic. An adequate selection of available resources of high didactic and pedagogical value is an urgent issue of distant learning. 
As participants of educational process are equally teachers and students, it is essential to take into account students' feedbacks of the internet resources they are offered to use on online lessons. Therefore, the purpose of this article is to investigate first-year biology students' perceptions of internet resources used during online English classes in 2020-2021 regarding their usefulness and effectiveness in reaching academic goals. The following tasks have facilitated the achievement of the purpose of the research:

- To describe internet resources and tools used to enrich the content of the discipline 'English for biology students (freshmen)' on online lessons during 2020-2021.

- To conduct the quantitative survey among students to define their motivation and preferences in utilizing offered internet resources and tools and rank them in terms of their effectiveness in learning Academic English for Biology.

- to determine students' accessibility of internet facilities since benefits from learning online directly depend on technical aspect (devices used for lessons, even their number in some cases, internet connectivity, internet speed, etc.).

- To draw conclusions on how the course can be improved for its further practical application to teaching Academic English for Biology online.

Theoretical background. Since March of 2020, Ukrainian universities have been facing a tremendous challenge of the shift from traditional in-class learning to online learning. Although such concepts as digital university, digitalization of higher education, hybrid learning have been actively discussed be academia in the last decade, the time to fully translate ideas into urgently needed practice has come only recently. Due to the outbreak of Coronavirus disease (COVID-19), universities closed down and lectures had to start online lessons in front of a computer screen while their students often had to leave the campus and do academic courses through the internet from home. In a short time, teachers took on roles of online instructors and gradually gained necessary digital skills to conduct lessons through Zoom, Skype, Microsoft Teams or Google meet and track students' progress in Google class. Consequently, in Ukrainian pedagogic discourse many articles have appeared shedding light on the particularities of online education in various universities and specialties. There could be traced two main tendencies: whereas some authors focus on general theoretical aspects of webucation in higher education settings in Ukraine (V. Areshonkov [4], O. Dereza, R. Sklyar, S. Dereza [1] O. Barna, O. Kuzminska [5], O. Kindratets [9] etc.), others devote their attention to particular case studies. Thus, O. Buinytska, L. VarchenkoTrotsenko, B. Hrytseliak. have considered the development of online education at Borys Grinchenko Kyiv University [6], V. Huzhva has investigated digital transformations at Kyiv National Economic University named after Vadym Hetman [7], N. Yehorchenkova has published a research on the implementation of the concept 'digital university' at National Aviation University [8], while A. Melnychenko and T. Zheliaskova have dealt with transformation of educational process in Covid-19 pandemic at Igor Sikorsky Kyiv Polytechnic Institute [2]. In their turn, N. Shumeiko \& A. Nypadymka have investigated students' readiness to handle independent research work before the beginning of the pandemic and then during the time of the COVID-19 pandemic at the Kyiv National University of Trade and Economics [3]. This wave of intense interest to online education illustrates not only a pressing need for digital transformations in higher education, but also a mere desire of the participants of this process to share practical experience of online teaching with academia and therefore to contribute to the establishment of digital university idea.

Methods. A methodological basis of this pilot study rests on general scientific principles of objectivity and systematicity. The data collection from biology students was conducted on the basis of quantitative and qualitative questionnaires. The first used questionnaire included questions that covered 3 sections in evaluation of educational internet resources: 1) technical quality (easyto-use browsing, absence of technical errors), 2) academic quality (information reliability, accuracy, clear presentation), 3) didactic quality (a variety of exercises aimed at the promotion of learning, interaction among students, learner's engagement). The evaluation was done using the scale from 1 (unacceptable) to 5 (excellent). Quantitative data were processed through SPSS statistics program. In its turn, the qualitative assessment questionnaire contained open questions to identify which basic linguistic skills (listening, speaking, reading, writing) the usage of internet resources helped students to improve. Additionally, learners were asked about their technical conditions (internet accessibility, appropriate work of sites, appropriate choice of devices) as reaching learning objectives online essentially depends on technical facilities.

Participants. In this pilot study, the data were collected from 32 biology students studying at the Institute of High Technologies and the Institute of Biology and Medicine of Taras Shevchenko National University of Kyiv. All of them were freshmen with the level of English ranging from B1+ to C1, which was defined by the entry placement test at the beginning of the academic year. It was their first experience of learning Academic English for Biology in a distant mode in higher educational setting.

Results. Within the course 6 educational internet resources were used to facilitate learning biological English, they were chosen on the basis of 3 criteria:

- Free to use,

- Match disciplinary content and epistemology,

- In line with learning objectives of the target audience.

These educational resources are as follows:

1. FutureLearn

Futurelearn.com is an educational online platform that offers a wide range of courses in a variety of subjects. The courses are designed by highly qualified educators from reputable universities and provide learning through diverse activities. Apart from reading scientific articles and watching videos, participants of these courses can take advantage of doing quizzes, taking an active part in group discussions, sharing thoughts in comments as well as directly putting questions to the tutors or reviewing their peers' works. Moreover, these courses not only enrich subject knowledge, they also promote critical thinking and significantly boost writing skills of participants. Finally, the evident plus is a wide choice of topics that are designed for various purposes (hobby, development of professional skills, change of career, etc.) and levels of knowledge (from beginners to postgraduate students and working professionals). As for life science, there are ample options for both biology and medical students, since available topics range from primary biology to such complex issues as human genome sequencing or $21^{\text {st }}$ century biorisks. In terms of learning ESP, these courses develop such skills as reading and listening comprehension as well as above mentioned writing skills. Besides, they often provide an extensive list of terms and their definitions. Also, they feature links to various useful supplementary materials. Last but not least, a wide choice of biology-related courses enables teachers to select the content that closely corresponds to the conceptual 
and methodological framework of their main discipline. All in all, FutureLearn is an educational platform that not only promotes contemporary modes of learning but enables single-minded people from all corners of the world to communicate without borders.

2. Khan Academy

While FutureLearn mainly aims at providing solid theoretical background in various subjects, Khanacademy.org resources for college students are based on the approach 'learning by doing'. Here student will face a challenge of solving complex sums and doing tests after watching explanatory videos or reading articles. In comparison to FutureLearn, this site provides more hands-on activities. Whereas a student obviously benefits acquiring subject knowledge, ESP learning comes only second. On the one hand, a student has to have a good command of academic English to comprehend theoretical explanations and do all the tasks afterwards. On the other, this resource gives little opportunity to train such basic language skill as writing, to say nothing of speaking. To sum up, Khan Academy's resources can be used to test how students can apply acquired theoretical knowledge in practice.

3. Tutorial channels on Youtube

Youtube.com is an online video sharing and social media platform, which has been the second most visited website in the world. It permits registered users to create their own channels, upload videos, form playlists, and call other users for subscription to the channels. There are currently a lot of life science channels that offer a vast collection of educational videos on various biological topics. Some of them are devoted solely to biology (i.e., iBiology, Moof University) whereas others cover many science subjects (i.e., MIT OpenCourseWare, CrashCourse), including biology. While watching videos on various topics, students primarily sharpen their listening skills. An enthusiastic teacher can use videos to develop exercises for group discussions or pairwork speaking activities. Within the course tutorials from RicochetScience and Crachcourse were mainly used.

4. Quizlet

Quizlet.com is an educational online platform that offers a lot of linguistic tools to learn terms and their definitions. It provides an affective algorithm for learning new words by the introduction of glossary with voice output and a set of tasks including games that strengthen students' listening, reading and spelling skills. A huge advantage is a wide choice of topics that feature various amounts of information. Thus, at the beginner level glossaries up to 20 or 30 lexical items can be chosen while for advanced students over a hundred terms can be offered. Besides, a teacher can create one's own sets of learning cards according to educational goals and needs. Quizlet doesn't provide a big picture of particular topic but gives an opportunity to effectively practice and memorize new lexical items.

5. Kahoot

Without exaggeration, Kahoot.com delivers engaging learning environment to billions of people around the world. At free basic level this site offers thematic games that can be used to test both subject knowledge and acquisition of English for Special Purposes. There are a lot of ready-to-use games that reveal various aspects of life sciences, some of which can be edited and modified in correspondence to a teacher's educational goals. Moreover, a user can create a personal account and make new games to encourage students to learn target vocabulary through playing games. These games can be created either for personal use only or made public to enrich global teaching community. More importantly, Kahoot.com has recently developed Kahoot app for Zoom to incorporate games directly into a tool bar of Zoom app. Unfortunately, this option is not free as well as advanced test options in games. Nevertheless, even at basic level Kahoot.com provides stimulating environment for teambuilding and allows acquiring a second language through games.

5. Crossword Labs

Crosswordlabs.com focuses on recognizing terms by given definitions. The resource features ready-to-use crosswords in various fields including biology and enables users to create their own definition activities for free. The crosswords can be solved online during a lesson to memorize new lexical units. Therefore, this site proves to be an effective supplementary tool to practice biological terms. The only thing is that the nature of this activity mainly implies the use of nouns and verbs. Similarly to Kahoot.com virtual platform, a teacher can create crosswords which are visible only to him or her, to selected users or to general public.

After the end of academic year students were asked to evaluate the above-mentioned resources using the 5 point scale, in which 5 stands for excellent, 4 - very good, above average, 3 - good, average, acceptable, 2 - weak,

less than acceptable, 1 - unacceptable, poor. This scale was applied in 3 main sections: 1) technical quality (user-friendly design, easy-to-use browsing, and absence of technical errors), 2) academic quality (information reliability, accuracy, and clear presentation), 3) didactic quality (a variety of exercises aimed at the promotion of learning, interaction among students, learner's engagement). To calculate average results in a target group, SPSS statistics program was used. The collected data allowed presenting the following results:

Statistical data and answers to open questions have revealed that students highly appreciated FutureLearn and Khan Academy for information reliability and accuracy and promotion of learning, although the first was considered somewhat more theoretical than practical so that less learner-engaging. Furthermore, they found Khan Academy the most appropriately matching their subject knowledge and therefore offering the most challenging problem-solving tasks. Both tutorial videos and a variety of tasks were designed in a balanced way with appropriate attention to detail. According to their feedbacks, task-solving helped them to improve their reading comprehension skills as well as 'feel' how biological terms are applied in practical environment. In there turn, Quizlet, Crossword Labs and Kahoot were considered to promote active learning, group interaction and learner's engagement as they contained a lot of games that are aimed at boosting vocabulary, testing subject knowledge and merely having fun in group competitions. At the same time, many students admitted numerous technical errors on Kahoot as they often were not able to reach the end of the game due to technical problems on the site. Moreover, Quizlet, Crossword Labs and Kahoot received lower points in terms of information reliability and accuracy as mistakes in pronunciation of terms, definitions of terms and explanation of concepts sometimes have been spotted by students. This is can be explained by the fact that, in comparison to FutureLearn and Khan Academy, the three analyzed resources present materials made by teachers from different educational and scientific backgrounds. It is not surprising that some concepts can vary from a country to a country or have different interpretations in various scientific practices, etc. As for tutorials on Youtube, it has been noticed that students quite often subjectively reacted to how information was presented or by whom it was delivered rather than what information they contained. Nevertheless, as tutorials were designed by subject teachers, students said that 
they helped them to feel themselves a part of global scientific community while staying at home during the lockdown. In general, it can be assumed that all above-mentioned resources can be used only as supplementary tools in achieving educational objectives and cannot replace face-to-face learning environment.

Additionally, students were asked about their internet accessibility and devices they used for online classes as their technical readiness to work effectively during the lesson directly depends on the available facilities. The data show that all the students experienced power cutoffs at least once while 14 (46,6\%) could not join cloud meetings due to this problem 3-5 times during the academic and 2 students $(7 \%$ ) reported to have permanent technical errors. At the same time, some students complained about slow internet connectivity (15\%) and all of them admitted the necessity to rejoin lessons several times because of inappropriate work of Zoom app. As for devices used during cloud meetings, it was revealed that all the students were able to use two gadgets during the lesson (most frequently a mobile phone (100\%) and a laptop (78 \%) were mentioned), but not always students had them at hand or could get connected from their working place. Learners admitted that they sometimes joined lessons either in public transport or public places due to various circumstances. To sum up, although online learning proves to be quite flexible in terms of students' mobility, technical facilities play an important role in sustainability of educational process.

Conclusions. The results of quantitative and qualitative surveys carried out among first-year biology students about usefulness of free educational internet resources, which were supposed to help them learn Academic English for Biology, made it possible to draw the following conclusions: the 6 resources fall into two main categories: those that provide balanced subject knowledge (Khan academy, FutureLearn, tutorial channels on Youtube) with no attention to linguistic needs of ESP learners, and those that can be used as linguistic tools to activate learning biological English (Kahoot, Quizlet, Crossword Labs). Consequently, FutureLearn, Khan Academy and tutorial channels on Youtube received high points for information reliability and accuracy whereas Quizlet and Kahoot were appreciated for promotion of group engagement and competition spirit. At the same time, Kahoot was criticized for technical errors.

In terms of language acquisition, students ideally should have an appropriate range of activities to improve four basic skills: reading, listening, writing and speaking. The offered internet tools could little facilitate promotion of speaking unless a teacher designed additional speaking exercises on the basis of the learning content. As for reading, listening, writing, all the resources helped students to boost their academic vocabulary, while Youtube mostly helped to sharpen listening skills, Quizlet, Crossword Labs were instrumental tools for correct spelling of terms. In their turn, FutureLearn and Khan Academy played a crucial role in the improvement of reading skills. As for writing, FutureLearn offered many writing activities. After the research it has become obvious that only a combination of educational internet tools that focus on promotion of particular aspects of learning can give fruitful results. Further investigation of the effectiveness of internet resources for learning Academic English for Biology may consider the evaluation of their pedagogical quality by university lecturers.

References:

1. Дереза О., Скляр Р., Дереза С. Методи навчання онлайн. Удосконалення освітньо-виховного процесу в закладі вищої освіти. 2020. Вип. 23. С. $82-90$

2. Melnychenko A., Zheliaskova T. Transformation of Educational Process in Covid-19 Pandemic: A Case of Igor Sikorsky Kyiv Polytechnic Institute. Advanced Education. 2021. № 8 (18). P. 4-10. URL: https://doi.org/10.20535/2410-8286.237575.

3. Shumeiko N., Nypadymka A. Ict-Supported Students' Independent Work in the Esp Context: The New Reality in Tertiary Education. Advanced Education. 2021. № 8(18). P. 79-91. URL: https://doi.org/10.20535/2410-8286.223286.

4. Арешонков В. Цифровізація вищої освіти: виклики та відповіді. Вісник Начіональної академії педагогічних наук України. 2021. № 2(2). URL: https://doi.org/10.37472/2707-305X-2020-2-2-13-2.

5. Барна О., Кузьмінська О. Визначення готовності закладу вищої освіти до цифрової трансформації. Сучасні інформаційні технології та інноваційні методики навчання: досвід, тенденції, перспективи: матеріали IV Міжнародної науково-практичної інтернет-конферениії, 30 квітня 2020 р. Тернопіль, 2020. С. 92-94. URL: http://dspace.tnpu.edu.ua/handle/123456789/15374.

6. Буйницька О., Варченко-Троценко Л., Грицеляк Б. Цифровізація закладу вищої освіти. Освіто-логічний дискурс. 2020 . № 1. C. 64-79. URL: https://doi.org/10.28925/2312-5829.2020.1.6.

7. Гужва В. Цифрова трансформація університетів. Східна Свропа: економіка, бізнес та управління. 2019. № 21. С. 597-604. URL: http://www.easterneuropeebm.in.ua/journal/21_2019/92.pdf.

8. Сгорченкова Н., Тесля Ю., Хлевна Ю., Кичань О. Методологічні аспекти створення цифрового університету. Вісник Наиіонального технічного університету «Харківський політехнічний інститут». Серія: Стратегічне управління, управління портфелями, програмами та проектами. 2020. № 1. С. 31-36. URL: https://doi.org/10.20998/2413-3000.2020.1.4.

9. Кіндратець О. Проблеми цифрової трансформації освіти. Освіта як чинник формування креативних компетентностей в умовах иифрового суспільства : збірка тез міжннародної науково-практичної конферениії, 27-28 листопада 2019 р. Запоріжжя, 2019. C. 59-60. URL: https://web.znu.edu.ua/NIS//2019/zbirka-tez.pdf. 